\title{
The effect of diabetes on mortality in critically ill patients: a systematic review and meta-analysis
}

\author{
Sarah E Siegelaar*, Maartje Hickmann, Joost BL Hoekstra, Frits Holleman and J Hans DeVries
}

\begin{abstract}
Introduction: Critically ill patients with diabetes are at increased risk for the development of complications, but the impact of diabetes on mortality is unclear. We conducted a systematic review and meta-analysis to determine the effect of diabetes on mortality in critically ill patients, making a distinction between different ICU types.

Methods: We performed an electronic search of MEDLINE and Embase for studies published from May 2005 to May 2010 that reported the mortality of adult ICU patients. Two reviewers independently screened the resultant 3,220 publications for information regarding ICU, in-hospital or 30-day mortality of patients with or without diabetes. The number of deaths among patients with or without diabetes and/or mortality risk associated with diabetes was extracted. When only crude survival data were provided, odds ratios (ORs) and standard errors were calculated. Data were synthesized using inverse variance with ORs as the effect measure. A random effects model was used because of anticipated heterogeneity.

Results: We included 141 studies comprising 12,489,574 patients, including 2,705,624 deaths (21.7\%). Of these patients, at least 2,327,178 (18.6\%) had diabetes. Overall, no association between the presence of diabetes and mortality risk was found. Analysis by ICU type revealed a significant disadvantage for patients with diabetes for all mortality definitions when admitted to the surgical ICU (ICU mortality: OR [95\% confidence interval] 1.48 [1.04 to 2.11]; in-hospital mortality: 1.59 [1.28 to 1.97]; 30-day mortality: 1.62 [1.13 to 2.34]). In medical and mixed ICUs, no effect of diabetes on all outcomes was found. Sensitivity analysis showed that the disadvantage in the diabetic surgical population was attributable to cardiac surgery patients (1.77 [1.45 to 2.16$], P<0.00001)$ and not to general surgery patients (1.21 [0.96 to 1.53$], P=0.11)$.
\end{abstract}

Conclusions: Our meta-analysis shows that diabetes is not associated with increased mortality risk in any ICU population except cardiac surgery patients.

Keywords: diabetes mellitus, critically ill, ICU mortality, in-hospital mortality, 30-day mortality, meta-analysis

\section{Introduction}

The proportion of patients with diabetes admitted to the ICU is growing as a result of the worldwide increase in type 2 diabetes. In cardiac surgery patients, the growth is even more pronounced, since patients with diabetesassociated, often complex, multivessel macrovascular complications are preferably treated surgically rather than by percutaneous intervention [1,2]. It is known that diabetic patients admitted to the ICU are more prone to develop complications [3-5], at least in part because of hampered immune cell function associated with the

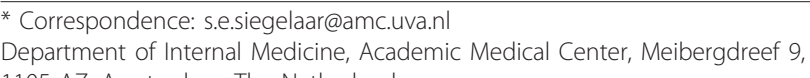

* Correspondence: s.e.siegelaar@amc.uva.nl
Department of Internal Medicine, Academic Medical Center, Meibergdreef 9, 1105 AZ, Amsterdam, The Netherlands
}

disease [6,7]. One would expect an increased mortality rate for diabetic ICU patients, but the literature at this point is conflicting, with reports of increased, equal or even decreased mortality rates among this population compared to patients without diabetes. Also, there might be a difference in outcomes between various ICU populations, such as cardiac surgery and medical patients.

To better understand the role of diabetes in critical illness, we conducted a systematic review and meta-analysis of studies regarding mortality, including observational as well as intervention studies that reported ICU, in-hospital and/or 30-day mortality rates of ICU-admitted patients with diabetes. 


\section{Materials and methods}

This study was conducted according to the recommendations of the Meta-analysis of Observational Studies in Epidemiology (MOOSE) group [8]. The study did not need ethical approval, since it was a retrospective analysis of anonymous data.

\section{Data sources and search strategy}

Together with the clinical librarian at our institution, an electronic search of MEDLINE and Embase from 1 May 2005 to 1 May 2010 was performed for studies that reported mortality of adult ICU patients, including both retrospective and prospective studies and both observational and intervention studies. The five-year limit was chosen because we expected that insulin treatment regimens and other therapies would be comparable among studies in this rapidly evolving field. The text terms and medical subheading, or MeSH, terms 'intensive care unit', 'critical care' and 'mortality' were combined. Since a preliminary search showed that diabetes was not always the primary interest of included studies, and to prevent publication bias, we narrowed the search by not using 'diabetes mellitus' as a search term. To avoid possible treatmentinduced bias, randomized controlled trials comparing intensive insulin therapy regimes were excluded [9]. We limited our search to research performed in adult human patient populations and published in the English-language literature. Unpublished studies were not identified.

\section{Study selection}

Two reviewers (SES and MH) independently screened the records. Agreement on final inclusion was reached by consensus. Inclusion and exclusion criteria were defined $a$ priori. A study was included if it reported crude ICU, inhospital and/or 30-day mortality of ICU-admitted patients with or without diabetes and/or included univariate or multivariate analysis of mortality risk for diabetic patients represented as odds ratios (ORs), hazard ratios or relative risks. Studies reporting 28- or 30-day mortality rates were combined. We excluded studies in which diabetes was the reason for ICU admittance, that is, ketoacidosis, as well as studies concerning patients with gestational diabetes and ICU readmissions. When it was not possible to obtain the full paper from our institutional library or the Internet, the corresponding author was contacted if the population included in the study was larger than 500 patients.

\section{Data extraction}

From the included publications the following data were extracted: first author, year of publication, country where the work was performed, study design, type of ICU, population specification, reported mortality type, definition of diabetes and the numbers of patients with and without diabetes. Subsequently, the number of deaths among patients with or without diabetes and/or the mortality risk associated with the presence of diabetes were extrapolated. We contacted the corresponding author for additional information when the publication reported only a $P$ value for mortality risk or when the exact number or proportion of patients with diabetes was not reported.

\section{Study quality}

No individual assessment of study quality was performed. Funnel plot analysis did not suggest any publication bias. We did not expect bias in outcome reporting, because death is a robust end point, and it is unlikely that patients were lost to follow-up, as the primary outcome was recorded in the hospital.

\section{Data synthesis and statistical methods}

The meta-analysis was performed using RevMan version 5 software (The Cochrane Collaboration, Oxford, UK). Analyses were performed separately for ICU, in-hospital and 30-day mortality as outcome variables. Data were synthesized using inverse variance with ORs as the effect measure. In the primary analysis, unadjusted results were used where possible. If only crude mortality data were provided, then the ORs and standard errors were calculated. An OR $>1$ suggested that diabetes was associated with an increased risk of death. We stratified the analyses by ICU type: trauma, surgical, medical and mixed. Data were pooled using a random effects model because heterogeneity between studies was anticipated. Heterogeneity was assessed using the $I^{2}$ statistic.

We performed sensitivity analyses to explore the robustness of the data and the influence of the following factors on effect size by repeating the analysis: (1) using a fixed instead of a random model, (2) leaving out the two largest studies, (3) making distinctions between cardiac and other types of surgery, (4) selecting and pooling only the five studies reporting unadjusted as well as adjusted outcomes and comparing these two effect sizes to assess the possible influence of confounders and (5) using adjusted instead of unadjusted effect sizes of those five studies in the in-hospital mortality analysis.

\section{Results}

Figure 1 summarizes the study identification and selection process. After removal of duplicates derived from the Embase and MEDLINE searches, 3,220 potentially interesting records were identified. Of these, we excluded 556 publications by reviewing the abstracts. After review of 2,664 full articles, 2,520 were excluded: 1,814 because no data at all were available regarding diabetes, 579 because mortality data were not available, 35 because they reported only long-term mortality and 2 duplicate publications were identified. We were not able to obtain 


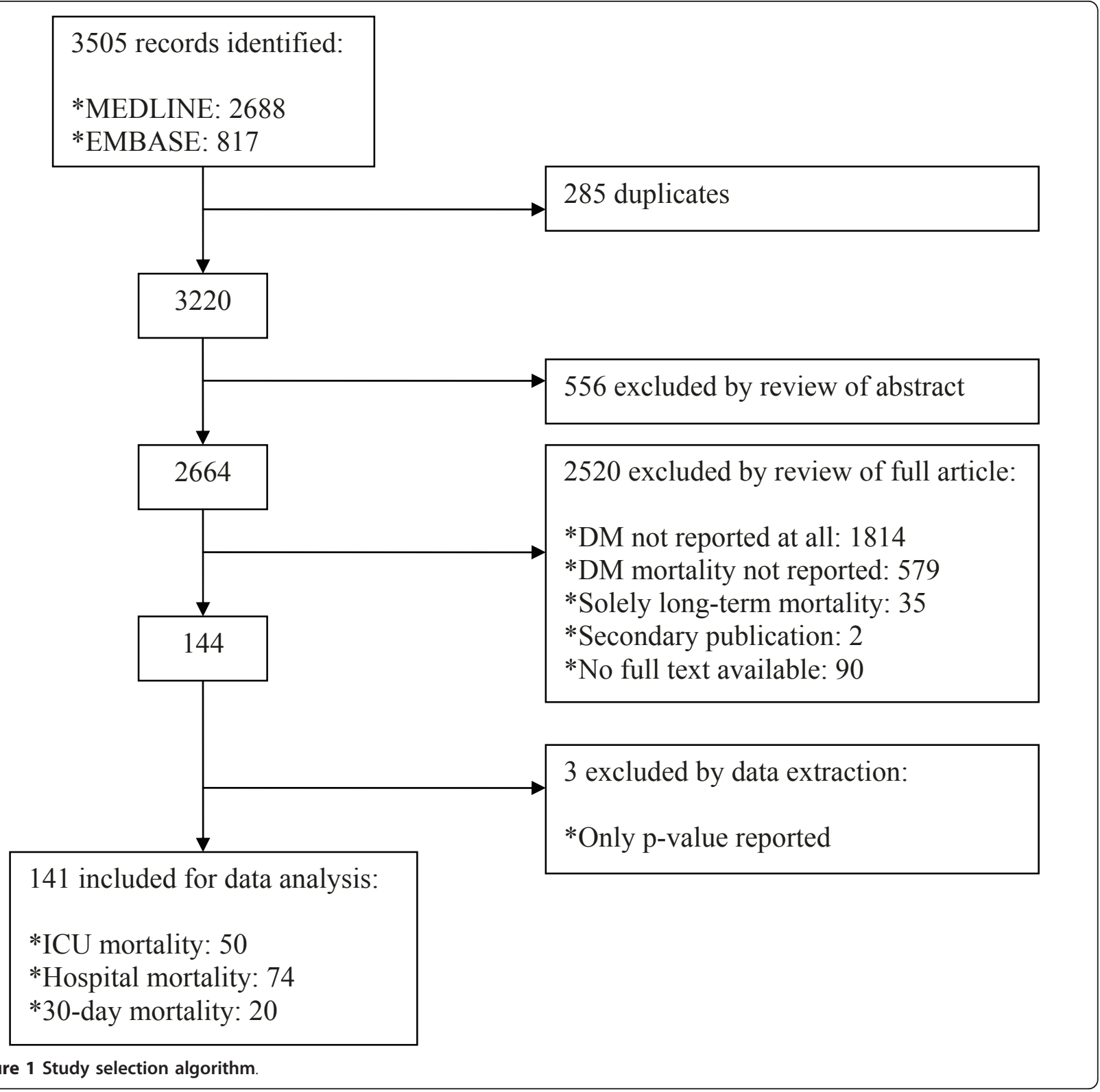

the full texts of 90 potentially relevant records, of which 14 reported a sample size of more than 500 participants. Three records were excluded by data extraction because only a $P$ value for mortality was reported and, after contacting the authors, the raw data could not be retrieved [10-12]. Finally, 141 studies could be included in the analysis of ICU mortality $(n=50$ [13-62]), in-hospital mortality $(n=74[26,63-135])$ and 30-day mortality $(n=20$ [65,128,136-153]). Three studies reported results of two outcome types: one comprised both ICU and in-hospital mortality [26] and two comprised both in-hospital and 30 -day mortality $[65,128]$. Only a few studies specified the type of diabetes of the patients included $(n=26)$. In most of these studies, diabetes was defined by the use of glucose-lowering drugs. A table listing the patient characteristics in the 141 included studies is presented in Additional file 1.

\section{ICU mortality}

The analysis of ICU mortality contained 52,908 patients, including 7,576 deaths (Figure 2). Of those patients, at least 8,852 were diagnosed with diabetes (16.7\%). In two studies, the number of patients with diabetes could not be retrieved $[59,62]$. Overall, pooling of the data showed no survival advantage for either group (OR 1.03, 95\% confidence interval $(95 \% \mathrm{CI}) 0.87$ to $\left.1.22, P=0.74, I^{2}=64 \%\right)$. Analysis by ICU type showed that in the surgical ICU, patients without diabetes did have a survival advantage 
over patients with diabetes (OR 1.48, 95\% CI 1.04 to 2.11 , $\left.P=0.03, I^{2}=0 \%\right)$ No differences were observed in the trauma, medical and mixed ICUs. Overall mortality was
$26.3 \%$ in general and/or cardiac surgical ICUs, $12.2 \%$ in trauma ICUs, $35.9 \%$ in medical ICUs and $11.8 \%$ in mixed ICUs. 


\section{In-hospital mortality}

The largest cohort could be analysed for in-hospital mortality: $12,403,355$ patients (mortality rate $21.7 \%$ ), of whom 2,313,466 patients (18.7\%) had diabetes (Figure 3). Pooling of all data did show a small mortality increase among the patients with diabetes (OR 1.08, 95\% CI 1.00 to $1.15, P=0.04, I^{2}=70 \%$ ). The disadvantage for patients with diabetes was attributable to the effect in the surgical patients (OR 1.59, 95\% CI 1.28 to $1.97, P<0.0001, I^{2}=$ $56 \%$ ) and trauma patients (OR $1.23,95 \%$ CI 1.12 to 1.36 , $\left.P<0.0001, I^{2}=0 \%\right)$ after stratifying by ICU type. In the medical and mixed ICUs, no difference in outcomes between the groups was seen. Overall mortality was 3.8\% in surgical ICUs, $5.1 \%$ in trauma ICUs, $24.2 \%$ in medical ICUs and $9.8 \%$ in mixed ICUs.

\section{Thirty-day mortality}

A total of 4,860 patients (25.5\%) with diabetes and 14,180 patients without diabetes were included in this analysis (Figure 4). For one study that included 14,271 patients, the proportions of patients with or without diabetes could not be retrieved [152]. Overall, there were no differences in mortality between the patients with or without diabetes (OR $1.19,95 \%$ CI 0.96 to $1.47, P=0.10, I^{2}=65 \%$ ). Stratifying the data for ICU type showed a difference in mortality favouring the patients without diabetes in the surgical ICU (OR $1.62,95 \%$ CI 1.13 to $2.34, P=0.009, I^{2}=54 \%$ ). Outcomes did not differ between groups in the medical and mixed ICUs. No separate analysis of trauma patients could be performed, since none of the studies reported 30-day mortality outcomes in a trauma ICU. Overall mortality was $2.5 \%$ in surgical ICUs, $34.6 \%$ in medical ICUs and $26.9 \%$ in mixed ICUs.

\section{Sensitivity analyses}

For ICU and 30-day mortality, the effect pointed in the same direction when using a fixed instead of a random model. No benefit was observed for patients with or without diabetes in the trauma ICUs, medical ICUs and mixed ICUs, but there was a significant disadvantage for surgical patients with diabetes. Regarding in-hospital mortality, the effect in the mixed and medical ICUs shifted towards an advantage for diabetes patients (medical: OR 0.89 [95\% CI 0.85 to 0.92 ], $P<0.00001$; OR mixed: 0.90 [95\% CI 0.88 to $0.92], P<0.00001)$. This effect was attributable to the weight of two very large studies. The medical ICU population in the study of Martin and colleagues [101] had an overall weight of $17.5 \%$; The mixed ICU population in the study of Graham and colleagues [26] had an overall weight of $69.9 \%$. Performing the fixed analysis without these two large studies resulted in the same conclusions as the random analysis, namely, no effect.

For all outcomes, we observed a mortality benefit for nondiabetic subjects in the surgical ICU. This population consisted of cardiac surgery patients as well as general surgery patients, who are quite distinct regarding the aetiology of their underlying disease compared to other ICU populations. We performed a sensitivity analysis to investigate whether the effect of diabetes might be different for cardiac surgery patients vs. general surgery patients. Since the effect was the same for ICU-, in-hospital and 30-day mortality outcomes and to increase power, we performed the sensitivity analysis by combining all studies of surgical ICU patients, regardless of mortality definition. This analysis showed that the increased mortality of patients with diabetes in the surgical ICU was mainly attributable to the 21 studies including cardiac surgery patients (OR $1.77,95 \%$ CI 1.45 to $2.16, P<$ $0.00001, I^{2}=49 \%$ ). Crude mortality was $5.1 \%$ for patients with diabetes and $3.3 \%$ for patients without diabetes. Pooling of the general surgery study data showed a trend towards higher mortality in diabetic patients (OR 1.21, 95\% CI 0.96 to $1.53, P=0.11, I^{2}=30 \%$ ).

Most studies reported only crude mortality data or unadjusted regression analyses. To assess the possible influence of confounders, we first looked at the data derived from five studies that reported unadjusted as well as adjusted results for in-hospital mortality $[26,65,75$, 95,121]. Among other parameters, these studies adjusted for severity of disease. Overall, no difference in effect size was observed after pooling the unadjusted results (OR 1.06 [ $95 \%$ CI 0.83 to 1.35$]$ ) vs. the adjusted results (OR 1.02 [95\% CI 0.79 to 1.34]). Introduction of adjusted instead of unadjusted data in the analysis of in-hospital mortality did not change the outcome, except for a shift towards nonsignificance in the analysis of the trauma patients (1.02 [95\% CI 0.93 to 1.13$], P=0.45, I^{2}=0 \%$ ).

\section{Discussion}

Our large meta-analysis shows no significant overall difference in mortality between critically ill patients with or without diabetes, except for the subgroup of cardiac surgery patients. We found a survival disadvantage for patients with diabetes admitted to the ICU after cardiac surgery. Our sensitivity analyses show good robustness of the data. If anything, using a fixed model shifts the outcome from equal survival towards a small benefit for diabetic patients in the medical and mixed ICU cohorts for in-hospital mortality, which can be attributed to the inclusion of two very large cohorts $[26,101]$. The clinical consequences are that patients with diabetes should not be denied access to ICUs on the basis of their diabetes. It is not possible, however, to draw conclusions regarding the possible benefits of tight glycaemia control in patients with diabetes on the basis of our meta-analysis.

It did not come as a surprise to us to find a negative impact of diabetes on the survival of cardiac surgery 


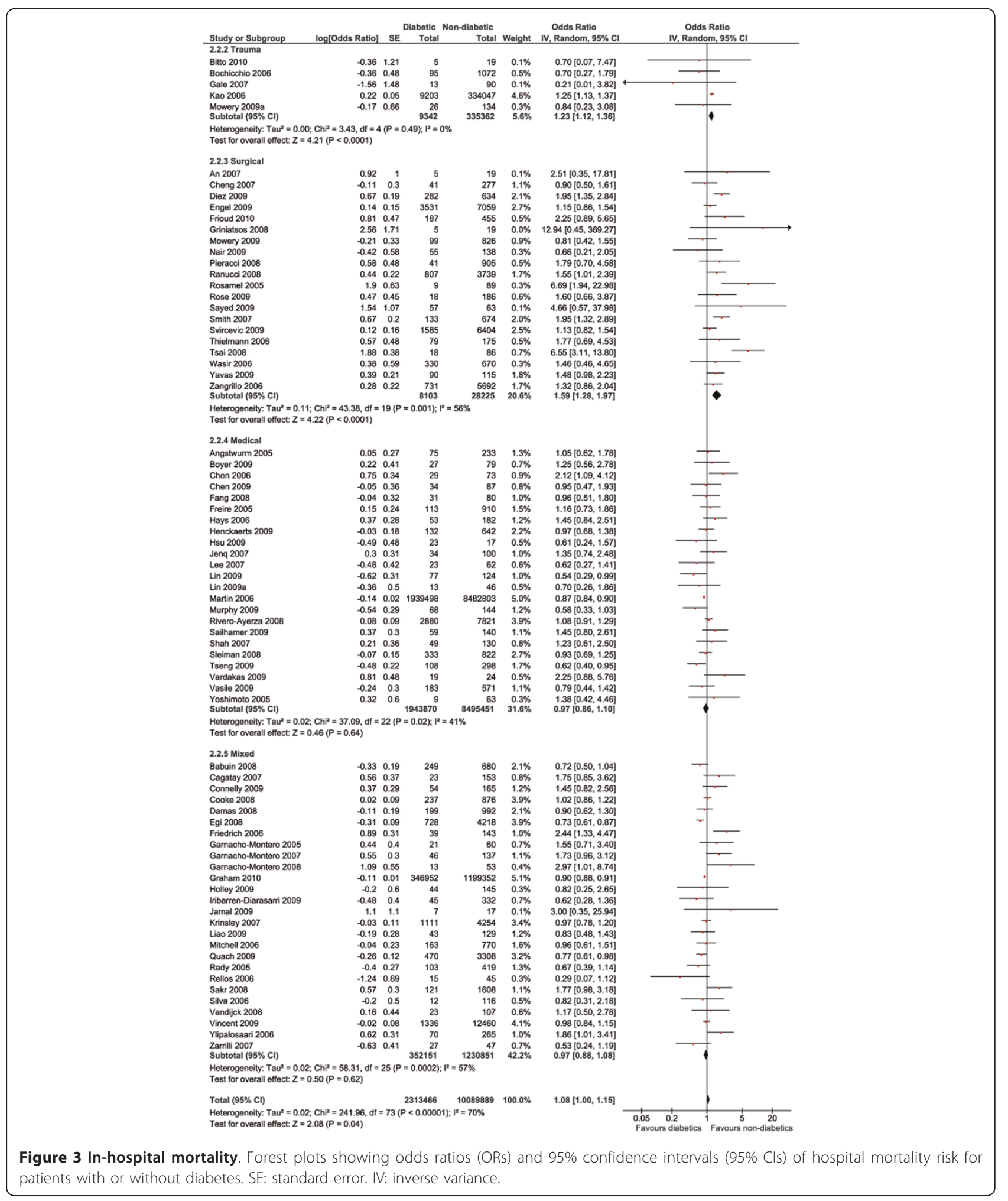

patients. The diabetic cardiac surgery population is different from the nondiabetic cardiac surgery population. As a result of their diabetes, diabetic cardiac surgery patients are more likely to have three-vessel coronary artery disease, left main coronary artery stenosis and left ventricular systolic dysfunction [154,155], all of which are associated with worse outcomes. Also, these patients are at increased risk for sternal wound infection, probably 


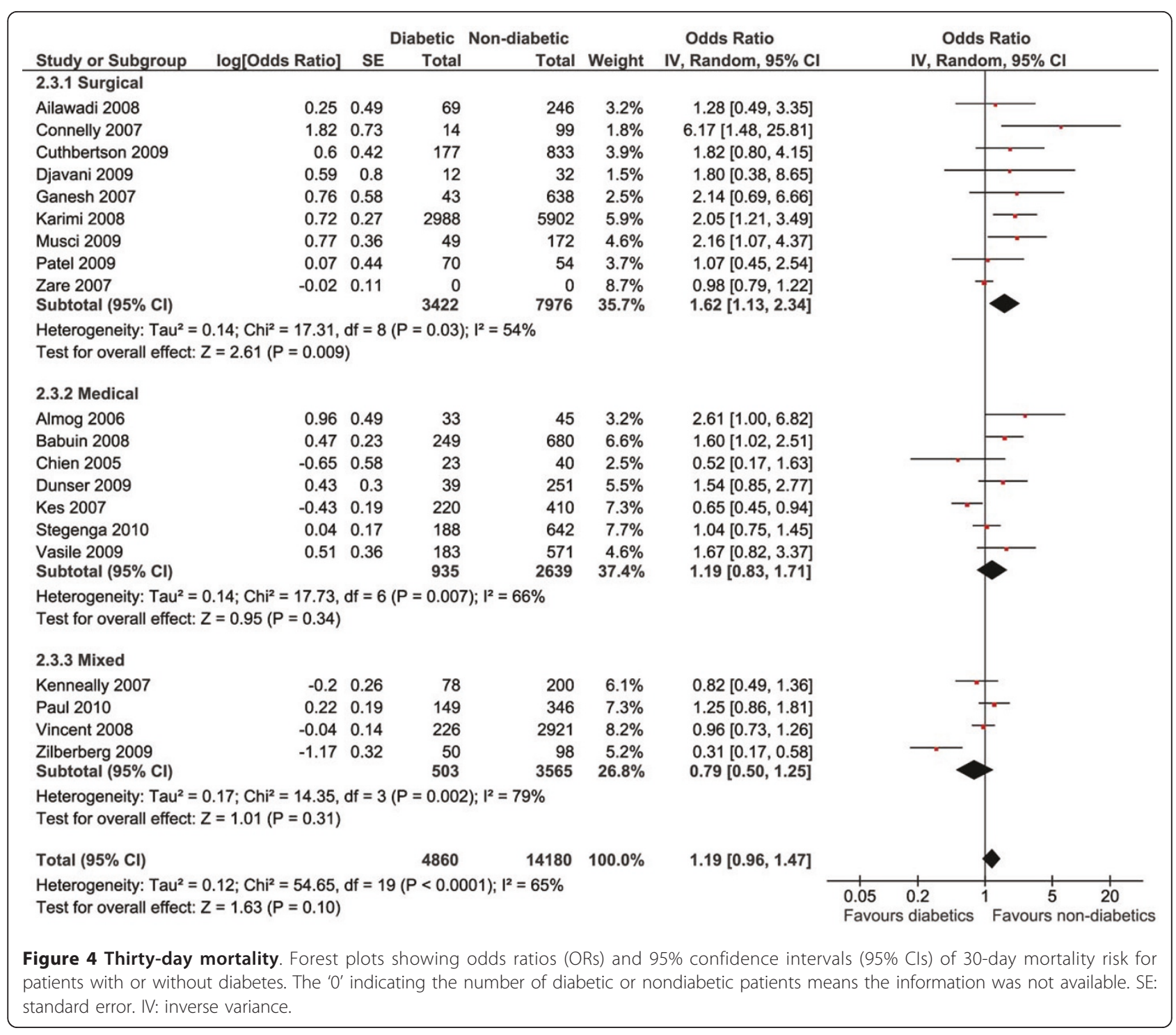

related to immune cell dysfunction associated with the disease [6,7].

On the other hand, it is remarkable to find no increased mortality for patients with diabetes in the medical and mixed ICU patient populations. Patients with diabetes are known to have a higher chance of developing complications such as sepsis and acute organ failure when they are admitted to the ICU [3-5]. These complications are associated with mortality, at least in the nondiabetic patient population. Apparently, diabetes is a risk factor only for the development of complications, but once acquired, the mortality risk is equal to or perhaps even lower than that of nondiabetic patients.

A possible explanation for the relative protection of critically ill patients with diabetes could lie in the different effects of stress-induced hyperglycaemia between the two groups. Hyperglycaemia is common in critically ill patients, and not only in those with diabetes. It is associated with mortality [156], but it has been shown that patients with diabetes are less affected than nondiabetic patients by high glucose levels $[26,77,157,158]$. It might be that the relative protection from stress-induced hyperglycaemia counteracts the increased mortality risk due to an increased amount of complications. Other mechanisms may, of course, contribute [26]. Further studies are needed to unravel the exact effects of hyperglycaemia in patients with or without diabetes.

Because of the nature of the included studies, we mainly show unadjusted results. It might be possible that the baseline characteristics between patients with or without diabetes were different, which would influence the outcome. If there were a difference, it would seem likely that patients with diabetes would be more severely ill at the time of admission. Adjusting for severity of illness would 
have decreased the ORs, as shown in the sensitivity analysis, thus indicating a greater advantage only for patients with diabetes. This effect is seen in the in-hospital mortality outcomes among the trauma patient population. It might be possible that adjustment for severity of disease decreases the negative effect of diabetes seen in cardiac surgery patients. However, our results represent the mortality risk of the average patient with or without diabetes, irrespective of the differences between the populations associated with diabetes.

There are limitations associated with our meta-analysis. First, the published data do not allow differentiating type 1 from type 2 diabetes or insulin-treated from non-insulintreated diabetes, and it might be possible that there are differences in outcomes between these groups. Furthermore, incomplete capture of diet-treated or undiagnosed diabetes in the included studies is likely, as most studies relied on the use of glucose-lowering drugs. Second, we could not retrieve mortality data from three studies. It is unlikely that including these three studies would have shifted the results to a disadvantage for patients with diabetes, since the $P$ values for mortality related to the presence of diabetes in these studies were not significant. Third, for 90 potentially relevant studies, the full articles could not be retrieved. These studies comprised a total of 48,263 patients, which would have contributed only $0.39 \%$ to the total population, so we expect that this had little influence on the outcomes. Fourth, the heterogeneity among studies was quite large. Fifth, the crude mortality rates in the three surgical populations were driven by the studies included: the high mortality rate in the surgical ICUs is heavily weighted by general surgery studies, whilst for in-hospital and 30-day mortality figures, the cardiac surgery studies with much lower mortality rates dominated.

\section{Conclusions}

We show in this meta-analysis that patients with diabetes who are admitted to medical, mixed and trauma ICUs have chances of survival similar to those of patients without diabetes. Diabetes significantly increases mortality risk only in patients admitted after surgery, more specifically after cardiac surgery, a population with distinct characteristics of the underlying disease. Further studies are needed to unravel the pathophysiological mechanisms by which patients with diabetes seem to be relatively protected in nonsurgical settings, despite higher complication rates.

\section{Key messages}

- Patients with diabetes admitted to medical, mixed and trauma ICUs have chances of survival similar to those of patients without diabetes.

- Patients with diabetes should not be denied access to ICU facilities on the basis of their diabetes.
- The presence of diabetes significantly increases mortality risk for patients admitted after cardiac surgery.

- The pathophysiological mechanisms by which patients with diabetes have equal mortality rates despite higher complication risks in nonsurgical settings should be a subject of further research.

\section{Additional material}

Additional file 1: Characteristics of the 141 studies included in the meta-analysis of ICU-, hospital- and 30-day mortality of patients with diabetes admitted to the ICU.

\section{Abbreviations}

Cl: confidence interval; DM: diabetes mellitus; OR: odds ratio; SE: standard error.

\section{Acknowledgements}

We acknowledge the contributions of Heleen C Dyserinck, Clinical Librarian, Academic Medical Center, Amsterdam, for her help in performing the literature search and Rob J Scholten, Department of Clinical Epidemiology, Biostatistics and Bioinformatics, Academic Medical Center, Amsterdam, for his excellent support in data extraction and synthesis.

\section{Authors' contributions}

SES contributed to the conception and design of the study; performed acquisition, analysis and interpretation of the data; and drafted the manuscript. MH contributed to the conception and design of the study, performed acquisition and analysis of the data and helped draft the manuscript. JBH contributed to the interpretation of the data and revised the manuscript for important intellectual content. FH and JHD contributed to the conception and design of the study and the interpretation of the data and revised the manuscript for important intellectual content. All authors gave their approval of the final version of the manuscript.

\section{Competing interests}

The authors declare that they have no competing interests. No funding was involved in the preparation of the manuscript.

Received: 16 May 2011 Revised: 20 July 2011

Accepted: 13 September 2011 Published: 13 September 2011

\section{References}

1. Abizaid A, Costa MA, Centemero M, Abizaid AS, Legrand VM, Limet RV, Schuler G, Mohr FW, Lindeboom W, Sousa AG, Sousa JE, van HB, Hugenholtz PG, Unger F, Serruys PW, Arterial Revascularization Therapy Study Group: Clinical and economic impact of diabetes mellitus on percutaneous and surgical treatment of multivessel coronary disease patients: insights from the Arterial Revascularization Therapy Study (ARTS) trial. Circulation 2001, 104:533-538.

2. Banning AP, Westaby S, Morice MC, Kappetein AP, Mohr FW, Berti S, Glauber M, Kellett MA, Kramer RS, Leadley K, Dawkins KD, Serruys PW: Diabetic and nondiabetic patients with left main and/or 3-vessel coronary artery disease: comparison of outcomes with cardiac surgery and paclitaxel-eluting stents. J Am Coll Cardiol 2010, 55:1067-1075.

3. Laupland KB, Gregson DB, Zygun DA, Doig CJ, Mortis G, Church DL: Severe bloodstream infections: a population-based assessment. Crit Care Med 2004, 32:992-997.

4. Michalia M, Kompoti M, Koutsikou A, Paridou A, Giannopoulou P, TrikkaGraphakos E, Clouva-Molyvdas P: Diabetes mellitus is an independent risk factor for ICU-acquired bloodstream infections. Intensive Care Med 2009, 35:448-454.

5. Slynkova K, Mannino DM, Martin GS, Morehead RS, Doherty DE: The role of body mass index and diabetes in the development of acute organ 
failure and subsequent mortality in an observational cohort. Crit Care 2006, 10:R137.

6. Alexiewicz JM, Kumar D, Smogorzewski M, Klin M, Massry SG: Polymorphonuclear leukocytes in non-insulin-dependent diabetes mellitus: abnormalities in metabolism and function. Ann Intern Med 1995, 123:919-924.

7. Marhoffer W, Stein M, Maeser E, Federlin K: Impairment of polymorphonuclear leukocyte function and metabolic control of diabetes. Diabetes Care 1992, 15:256-260.

8. Stroup DF, Berlin JA, Morton SC, Olkin I, Williamson GD, Rennie D, Moher D, Becker BJ, Sipe TA, Thacker SB: Meta-analysis of observational studies in epidemiology: a proposal for reporting. Meta-analysis Of Observational Studies in Epidemiology (MOOSE) group. JAMA 2000, 283:2008-2012

9. Siegelaar SE, Hoekstra JB, DeVries JH: Special considerations for the diabetic patient in the ICU: targets for treatment and risks of hypoglycaemia. Best Pract Res Clin Endocrinol Metab

10. Kao HK, Chang KP, Ching WC, Tsao CK, Cheng MH, Wei FC: Postoperative morbidity and mortality of head and neck cancers in patients with liver cirrhosis undergoing surgical resection followed by microsurgical free tissue transfer. Ann Surg Oncol 2010, 17:536-543.

11. Ligtenberg JJ, Meijering S, Stienstra Y, van der Horst IC, Vogelzang M, Nijsten MW, Tulleken JE, Zijlstra JG: Mean glucose level is not an independent risk factor for mortality in mixed ICU patients. Intensive Care Med 2006, 32:435-438.

12. Wahl WL, Taddonio M, Maggio PM, Arbabi S, Hemmila MR: Mean glucose values predict trauma patient mortality. J Trauma 2008, 65:42-47.

13. Andrikos E, Tseke P, Balafa O, Cruz DN, Tsinta A, Androulaki M, Pappas M, Ronco C: Epidemiology of acute renal failure in ICUs: a multi-center prospective study. Blood Purif 2009, 28:239-244.

14. Auburtin M, Wolff M, Charpentier J, Varon E, Le Tulzo Y, Girault C, Mohammedi I, Renard B, Mourvillier B, Bruneel F, Ricard JD, Timsit JF: Detrimental role of delayed antibiotic administration and penicillinnonsusceptible strains in adult intensive care unit patients with pneumococcal meningitis: the PNEUMOREA prospective multicenter study. Crit Care Med 2006, 34:2758-2765.

15. Barlage S, Gnewuch C, Liebisch G, Wolf Z, Audebert FX, Glück T, Fröhlich D, Krämer BK, Rothe G, Schmitz G: Changes in HDL-associated apolipoproteins relate to mortality in human sepsis and correlate to monocyte and platelet activation. Intensive Care Med 2009, 35:1877-1885.

16. Bodí M, Rodríguez A, Solé-Violán J, Gilavert MC, Garnacho J, Blanquer J, Jimenez J, de la Torre MV, Sirvent JM, Almirall J, Doblas A, Badía JR, García F, Mendia A, Jordá R, Bobillo F, Vallés J, Broch MJ, Carrasco N, Herranz MA, Rello J, Community-Acquired Pneumonia Intensive Care Units (CAPUCI) Study Investigators: Antibiotic prescription for communityacquired pneumonia in the intensive care unit: impact of adherence to Infectious Diseases Society of America guidelines on survival. Clin Infect Dis 2005, 41:1709-1716.

17. Britt RC, Devine A, Swallen KC, Weireter LJ, Collins JN, Cole FJ, Britt LD: Corticosteroid use in the intensive care unit: at what cost? Arch Surg 2006, 141:145-149.

18. Chan KP, Low JG, Raghuram J, Fook-Chong SM, Kurup A: Clinical characteristics and outcome of severe melioidosis requiring intensive care. Chest 2005, 128:3674-3678.

19. Chen W, Chen CH, Chiu KL, Lai HC, Liao KF, Ho YJ, Hsu WH: Clinical outcome and prognostic factors of patients with pyogenic liver abscess requiring intensive care. Crit Care Med 2008, 36:1184-1188.

20. Degoricija V, Sharma M, Legac A, Gradišer M, Šefer S, Vučičević Ž: Survival analysis of 314 episodes of sepsis in medical intensive care unit in university hospital: impact of intensive care unit performance and antimicrobial therapy. Croat Med J 2006, 47:385-397.

21. Egi M, Bellomo R, Stachowski E, French CJ, Hart G: Variability of blood glucose concentration and short-term mortality in critically ill patients. Anesthesiology 2006, 105:244-252.

22. Erbes $R$, Oettel K, Raffenberg M, Mauch H, Schmidt-loanas M, Lode $H$ : Characteristics and outcome of patients with active pulmonary tuberculosis requiring intensive care. Eur Respir J 2006, 27:1223-1228.

23. Fortaleza CR, Melo EC, Fortaleza CM: Nasopharyngeal colonization with methicillin-resistant Staphylococcus aureus and mortality among patients in an intensive care unit. Rev Lat Am Enfermagem 2009, 17:677-682.

24. Georges H, Chiche A, Alfandari S, Devos P, Boussekey N, Leroy O: Adult community-acquired bacterial meningitis requiring ICU admission: epidemiological data, prognosis factors and adherence to IDSA guidelines. Eur J Clin Microbiol Infect Dis 2009, 28:1317-1325.

25. Gong MN, Thompson BT, Williams PL, Zhou W, Wang MZ, Pothier L, Christiani DC: Interleukin-10 polymorphism in position -1082 and acute respiratory distress syndrome. Eur Respir J 2006, 27:674-681.

26. Graham BB, Keniston A, Gajic O, Trillo Alvarez CA, Medvedev S, Douglas IS: Diabetes mellitus does not adversely affect outcomes from a critical illness. Crit Care Med 2010, 38:16-24.

27. Kermarrec N, Marmuse JP, Faivre J, Lasocki S, Mognol P, Chosidow D, Muller C, Desmonts JM, Montravers P: High mortality rate for patients requiring intensive care after surgical revision following bariatric surgery. Obes Surg 2008, 18:171-178.

28. Labelle AJ, Micek ST, Roubinian N, Kollef MH: Treatment-related risk factors for hospital mortality in Candida bloodstream infections. Crit Care Med 2008, 36:2967-2972.

29. Lan MY, Wu SJ, Chang YY, Chen WH, Lai SL, Liu JS: Neurologic and nonneurologic predictors of mortality in ischemic stroke patients admitted to the intensive care unit. J Formos Med Assoc 2006, 105:653-658.

30. Lemant J, Boisson V, Winer A, Thibault L, André H, Tixier F, Lemercier M, Antok E, Cresta MP, Grivard P, Besnard M, Rollot O, Favier F, Huerre M, Campinos $J L$, Michault A: Serious acute Chikungunya virus infection requiring intensive care during the Reunion Island outbreak in 20052006. Crit Care Med 2008, 36:2536-2541.

31. Leroy O, Gangneux JP, Montravers P, Mira JP, Gouin F, Sollet JP, Carlet J, Reynes J, Rosenheim M, Regnier B, Lortholary O, AmarCand Study Group: Epidemiology, management, and risk factors for death of invasive Candida infections in critical care: a multicenter, prospective, observational study in France (2005-2006). Crit Care Med 2009, 37:1612-1618.

32. Lorente L, Martín MM, Labarta L, Díaz C, Solé-Violán J, Blanquer J, Orbe J, Rodríguez JA, Jiménez A, Borreguero-León JM, Belmonte F, Medina JC, Llimiñana MC, Ferrer-Agüero JM, Ferreres J, Mora ML, Lubillo S, Sánchez M, Barrios Y, Sierra A, Páramo JA: Matrix metalloproteinase- $9,-10$, and tissue inhibitor of matrix metalloproteinases-1 blood levels as biomarkers of severity and mortality in sepsis. Crit Care 2009, 13:R158.

33. Lundelin K, Vigil L, Bua S, Gomez-Mestre I, Honrubia T, Varela M: Differences in complexity of glycemic profile in survivors and nonsurvivors in an intensive care unit: a pilot study. Crit Care Med 2010, 38:849-854.

34. Markogiannakis H, Pachylaki N, Samara E, Kalderi M, Minettou M, Toutouza M, Toutouzas KG, Theodorou D, Katsaragakis S: Infections in a surgical intensive care unit of a university hospital in Greece. Int I Infect Dis 2009, 13:145-153

35. Martin-Loeches I, Lisboa T, Rodriguez A, Putensen C, Annane D, GarnachoMontero J, Restrepo Ml, Rello J: Combination antibiotic therapy with macrolides improves survival in intubated patients with communityacquired pneumonia. Intensive Care Med 2010, 36:612-620.

36. Mascia L, Sakr Y, Pasero D, Payen D, Reinhart K, Vincent JL, Sepsis Occurrence in Acutely III Patients (SOAP) Investigators: Extracranial complications in patients with acute brain injury: a post-hoc analysis of the SOAP study. Intensive Care Med 2008, 34:720-727.

37. Murthy SC, Arroliga AC, Walts PA, Feng J, Yared JP, Lytle BW, Blackstone EH: Ventilatory dependency after cardiovascular surgery. J Thorac Cardiovasc Surg 2007, 134:484-490.

38. Nasraway SA Jr, Albert M, Donnelly AM, Ruthazer R, Shikora SA, Saltzman E: Morbid obesity is an independent determinant of death among surgical critically ill patients. Crit Care Med 2006, 34:964-971.

39. Nseir S, Di Pompeo C, Cavestri B, Jozefowicz E, Nyunga M, Soubrier S, Roussel-Delvallez M, Saulnier F, Mathieu D, Durocher A: Multiple-drugresistant bacteria in patients with severe acute exacerbation of chronic obstructive pulmonary disease: prevalence, risk factors, and outcome. Crit Care Med 2006, 34:2959-2966.

40. Ong AW, Omert LA, Vido D, Goodman BM, Protetch J, Rodriguez A, Jeremitsky E: Characteristics and outcomes of trauma patients with ICU lengths of stay 30 days and greater: a seven-year retrospective study. Crit Care 2009, 13:R154

41. Patel GP, Simon D, Scheetz M, Crank CW, Lodise T, Patel N: The effect of time to antifungal therapy on mortality in candidemia associated septic shock. Am J Ther 2009, 16:508-511.

42. Pratikaki M, Platsouka E, Sotiropoulou C, Vassilakopoulos T, Paniara O, Roussos C, Routsi C: Risk factors for and influence of bloodstream 
infections on mortality: a 1-year prospective study in a Greek intensivecare unit. Epidemiol Infect 2009, 137:727-735.

43. Rammaert B, Verdier N, Cavestri B, Nseir S: Procalcitonin as a prognostic factor in severe acute exacerbation of chronic obstructive pulmonary disease. Respirology 2009, 14:969-974.

44. Reintam A, Parm P, Kitus R, Kern H, Starkopf J: Primary and secondary intra-abdominal hypertension: different impact on ICU outcome. Intensive Care Med 2008, 34:1624-1631.

45. Rhodes A, Wort SJ, Thomas H, Collinson P, Bennett ED: Plasma DNA concentration as a predictor of mortality and sepsis in critically ill patients. Crit Care 2006, 10:R60.

46. Riachy M, Sfeir F, Sleilaty G, Hage-Chahine S, Dabar G, Bazerbachi T, AounBacha Z, Khayat G, Koussa S: Prediction of the survival and functional ability of severe stroke patients after ICU therapeutic intervention. BMC Neurol 2008, 8:24.

47. Rodriguez A, Lisboa T, Blot S, Martin-Loeches I, Solé-Violán J, De Mendoza D, Rello J, Community-Acquired Pneumonia Intensive Care Units (CAPUCI) Study Investigators: Mortality in ICU patients with bacterial community-acquired pneumonia: when antibiotics are not enough. Intensive Care Med 2009, 35:430-438.

48. Ruiz-Bailén M, Brea-Salvago JF, de Hoyos EA, Rucabado-Aguilar L, Escudero GG, Martínez-Escobar S, Rossel-Ortiz F, Mellado-Vergel JF, RuizFerrón F, Morante-Valle A, Gómez-Jiménez FJ, Colmenero-Ruiz M, ARIAM Group: Post-thrombolysis intracerebral hemorrhage: data from the Spanish Register ARIAM. Crit Care Med 2005, 33:1829-1838.

49. Sakr Y, Reinhart K, Vincent JL, Sprung CL, Moreno R, Ranieri VM, De Backer D, Payen D: Does dopamine administration in shock influence outcome? Results of the Sepsis Occurrence in Acutely III Patients (SOAP) Study. Crit Care Med 2006, 34:589-597.

50. Santini M, Kutlesa M, Pangercic A, Barsic B: The importance of pathogens in sepsis Staphylococcus aureus story. Scand J Infect Dis 2010, 42:172-176.

51. Senthuran S, Bandeshe H, Ranganathan D, Boots R: Outcomes for dialysis patients with end-stage renal failure admitted to an intensive care unit or high dependency unit. Med J Aust 2008, 188:292-295.

52. Swoboda S, Ober M, Hainer C, Lichtenstern C, Seiler C, Wendt C, HoppeTichy $T$, Büchler $M$, Weigand MA: Tigecycline for the treatment of patients with severe sepsis or septic shock: a drug use evaluation in a surgical intensive care unit. J Antimicrob Chemother 2008, 61:729-733.

53. Tseng CC, Fang WF, Chung YH, Wang YH, Douglas IS, Lin MC: Clinical outcomes in patients with ICU-related pancreatitis. World I Gastroenterol 2009, 15:4938-4944.

54. Valente S, Lazzeri C, Saletti E, Chiostri M, Gensini GF: Primary percutaneous coronary intervention in comatose survivors of cardiac arrest with STelevation acute myocardial infarction: a single-center experience in Florence. J Cardiovasc Med (Hagerstown) 2008, 9:1083-1087.

55. Varela M, Calvo M, Chana M, Gomez-Mestre I, Asensio R, Galdos P: Clinical implications of temperature curve complexity in critically ill patients. Crit Care Med 2005, 33:2764-2771

56. Wang JL, Chin CS, Chang MC, Yi CY, Shih SJ, Hsu JY, Wu CL: Key process indicators of mortality in the implementation of protocol-driven therapy for severe sepsis. J Formos Med Assoc 2009, 108:778-787.

57. Whitcomb BW, Pradhan EK, Pittas AG, Roghmann MC, Perencevich EN: Impact of admission hyperglycemia on hospital mortality in various intensive care unit populations. Crit Care Med 2005, 33:2772-2777.

58. Wilson PA, Ferguson J: Severe community-acquired pneumonia: an Australian perspective. Intern Med J 2005, 35:699-705.

59. Wu J, Sheng L, Ma Y, Gu J, Zhang M, Gan J, Xu S, Jiang G: The analysis of risk factors of impacting mortality rate in severe multiple trauma patients with posttraumatic acute respiratory distress syndrome. Am J Emerg Med 2008, 26:419-424.

60. Yu TJ, Liu YC, Yu CC, Tseng JC, Hua CC, Wu HP: Comparing hydrocortisone and methylprednisolone in patients with septic shock. Adv Ther 2009, 26:728-735.

61. Zaragoza R, Pemán J, Quindós G, Iruretagoyena JR, Cuétara MS, Ramírez P, Gómez MD, Camarena JJ, Viudes A, Pontón J, Candida albicans Germ Tube Antibody Detection in Critically III Patients (CAGTAUCI): Clinical significance of the detection of Candida albicans germ tube-specific antibodies in critically ill patients. Clin Microbiol Infect 2009, 15:592-595.

62. Zhao XG, Wu JS, He XD, Ma YF, Zhang M, Gan JX, Xu SW, Jiang GY: Risk factors of mortality in road traffic injury patients with acute respiratory distress syndrome. Chin Med J (Engl) 2008, 121:968-972.
63. An Y, Xiao YB, Zhong QJ: Open-heart surgery in patients with liver cirrhosis. Eur J Cardiothorac Surg 2007, 31:1094-1098.

64. Angstwurm MW, Gaertner R, Schopohl J: Outcome in elderly patients with severe infection is influenced by sex hormones but not gender. Crit Care Med 2005, 33:2786-2793.

65. Babuin L, Vasile VC, Rio Perez JA, Alegria JR, Chai HS, Afessa B, Jaffe AS: Elevated cardiac troponin is an independent risk factor for short- and long-term mortality in medical intensive care unit patients. Crit Care Med 2008, 36:759-765.

66. Bitto A, Barone M, David A, Polito F, Familiari D, Monaco F, Giardina M, David T, Messina R, Noto A, Di Stefano V, Altavilla D, Bonaiuto A, Minutoli L, Guarini S, Ottani A, Squadrito F, Venuti FS: High mobility group box-1 expression correlates with poor outcome in lung injury patients. Pharmacol Res 2010, 61:116-120.

67. Bochicchio GV, Joshi M, Bochicchio K, Nehman S, Tracy JK, Scalea TM: Impact of obesity in the critically ill trauma patient: a prospective study. J Am Coll Surg 2006, 203:533-538.

68. Boyer A, Vargas F, Coste F, Saubusse E, Castaing Y, Gbikpi-Benissan G, Hilbert G, Gruson D: Influence of surgical treatment timing on mortality from necrotizing soft tissue infections requiring intensive care management. Intensive Care Med 2009, 35:847-853.

69. Çağatay AA, Özcan PE, Gulec L, Ince N, Tugrul S, Özsüt H, Cakar N, Esen F, Eraksoy H, Calangu S: Risk factors for mortality of nosocomial bacteraemia in intensive care units. Med Princ Pract 2007, 16:187-192.

70. Chen YC, Tian YC, Liu NJ, Ho YP, Yang C, Chu YY, Chen PC, Fang JT, Hsu CW, Yang CW, Tsai MH: Prospective cohort study comparing sequential organ failure assessment and acute physiology, age, chronic health evaluation III scoring systems for hospital mortality prediction in critically ill cirrhotic patients. Int J Clin Pract 2006, 60:160-166.

71. Chen YC, Jenq CC, Tian YC, Chang MY, Lin CY, Chang CC, Lin HC, Fang JT, Yang CW, Lin SM: RIFLE classification for predicting in-hospital mortality in critically ill sepsis patients. Shock 2009, 31:139-145.

72. Cheng B, Xie G, Yao S, Wu X, Guo Q, Gu M, Fang Q, Xu Q, Wang D, Jin Y, Yuan S, Wang J, Du Z, Sun Y, Fang X: Epidemiology of severe sepsis in critically ill surgical patients in ten university hospitals in China. Crit Care Med 2007, 35:2538-2546.

73. Connelly SM, Trinh JV, Johnson MD, Dodds-Ashley ES, Stout J, Engemann JJ, Friedman ND, Kaye D, Kaye KS: Mortality and time to extubation in severe hospital-acquired pneumonia. Am J Infect Control 2009, 37:143-149.

74. Cooke CR, Kahn JM, Caldwell E, Okamoto VN, Heckbert SR, Hudson LD, Rubenfeld GD: Predictors of hospital mortality in a population-based cohort of patients with acute lung injury. Crit Care Med 2008, 36:1412-1420.

75. Damas P, Ledoux D, Nys M, Monchi M, Wiesen P, Beauve B, Preiser JC: Intensive care unit acquired infection and organ failure. Intensive Care Med 2008, 34:856-864.

76. Diez C, Mohr P, Kuss O, Osten B, Silber RE, Hofmann HS: Impact of preoperative renal dysfunction on in-hospital mortality after solitary valve and combined valve and coronary procedures. Ann Thorac Surg 2009, 87:731-736

77. Egi M, Bellomo R, Stachowski E, French CJ, Hart GK, Hegarty C, Bailey M: Blood glucose concentration and outcome of critical illness: the impact of diabetes. Crit Care Med 2008, 36:2249-2255.

78. Engel AM, McDonough S, Smith JM: Does an obese body mass index affect hospital outcomes after coronary artery bypass graft surgery? Ann Thorac Surg 2009, 88:1793-1800.

79. Fang JT, Tsai MH, Tian YC, Jenq CC, Lin CY, Chen YC, Lien JM, Chen PC, Yang CW: Outcome predictors and new score of critically ill cirrhotic patients with acute renal failure. Nephrol Dial Transplant 2008, 23:1961-1969.

80. Freire $A X$, Bridges $L$, Umpierrez GE, Kuhl D, Kitabchi AE: Admission hyperglycemia and other risk factors as predictors of hospital mortality in a medical ICU population. Chest 2005, 128:3109-3116.

81. Friedrich JO, Wilson G, Chant C: Long-term outcomes and clinical predictors of hospital mortality in very long stay intensive care unit patients: a cohort study. Crit Care 2006, 10:R59.

82. Frioud A, Comte-Perret S, Nguyen S, Berger MM, Ruchat P, Ruiz J: Blood glucose level on postoperative day 1 is predictive of adverse outcomes after cardiovascular surgery. Diabetes Metab 2010, 36:36-42.

83. Gale SC, Sicoutris C, Reilly PM, Schwab CW, Gracias VH: Poor glycemic control is associated with increased mortality in critically ill trauma patients. Am Surg 2007, 73:454-460. 
84. Garnacho-Montero J, Ortiz-Leyba C, Fernández-Hinojosa E, Aldabó-Pallás T, Cayuela A, Marquez-Vacáro JA, Garcia-Curiel A, Jiménez-Jiménez FJ: Acinetobacter baumannii ventilator-associated pneumonia: epidemiological and clinical findings. Intensive Care Med 2005, 31:649-655.

85. Garnacho-Montero J, Sa-Borges M, Solé-Violán J, Barcenilla F, EscorescaOrtega A, Ochoa M, Cayuela A, Rello J: Optimal management therapy for Pseudomonas aeruginosa ventilator-associated pneumonia: an observational, multicenter study comparing monotherapy with combination antibiotic therapy. Crit Care Med 2007, 35:1888-1895.

86. Garnacho-Montero J, Aldabó-Pallás T, Palomar-Martínez M, Vallés J, Almirante B, Garcés R, Grill F, Pujol M, Arenas-Giménez C, Mesalles E, Escoresca-Ortega A, de Cueto M, Ortiz-Leyba C: Risk factors and prognosis of catheter-related bloodstream infection in critically ill patients: a multicenter study. Intensive Care Med 2008, 34:2185-2193.

87. Griniatsos J, Petrou A, Pappas P, Revenas K, Karavokyros I, Michail OP, Tsigris C, Giannopoulos A, Felekouras E: Percutaneous cholecystostomy without interval cholecystectomy as definitive treatment of acute cholecystitis in elderly and critically ill patients. South Med J 2008, 101:586-590.

88. Hays A, Diringer MN: Elevated troponin levels are associated with higher mortality following intracerebral hemorrhage. Neurology 2006, 66:1330-1334

89. Henckaerts L, Nielsen KR, Steffensen R, Van SK, Mathieu C, Giulietti A, Wouters PJ, Milants I, Vanhorebeek I, Langouche L, Vermeire S, Rutgeerts P, Thiel S, Wilmer A, Hansen TK, Van den Berghe G: Polymorphisms in innate immunity genes predispose to bacteremia and death in the medical intensive care unit. Crit Care Med 2009, 37:192-193.

90. Holley A, Dulhunty J, Blot S, Lipman J, Lobo S, Dancer C, Rello J, Dimopoulos G: Temporal trends, risk factors and outcomes in albicans and non-albicans candidaemia: an international epidemiological study in four multidisciplinary intensive care units. Int J Antimicrob Agents 2009, 33:554-557.

91. Hsu CL, Chang CH, Wong KN, Chen KY, Yu CJ, Yang PC: Management of severe community-acquired septic meningitis in adults: from emergency department to intensive care unit. J Formos Med Assoc 2009, 108:112-118.

92. Iribarren-Diarasarri S, Aizpuru-Barandiaran F, Muñoz-Martínez T, LomaOsorio Á, Hernández-López M, Ruiz-Zorrilla JM, Castillo-Arenal C, Dudagoitia-Otaolea JL, Martínez-Alutiz S, Vinuesa-Lozano C: Health-related quality of life as a prognostic factor of survival in critically ill patients. Intensive Care Med 2009, 35:833-839.

93. Jamal W, Salama M, Dehrab N, Al Hashem G, Shahin M, Rotimi VO: Role of tigecycline in the control of a carbapenem-resistant Acinetobacter baumannii outbreak in an intensive care unit. J Hosp Infect 2009, 72:234-242.

94. Jenq CC, Tsai MH, Tian YC, Lin CY, Yang C, Liu NJ, Lien JM, Chen YC, Fang JT, Chen PC, Yang CW: RIFLE classification can predict short-term prognosis in critically ill cirrhotic patients. Intensive Care Med 2007, 33:1921-1930.

95. Kao LS, Todd SR, Moore FA: The impact of diabetes on outcome in traumatically injured patients: an analysis of the National Trauma Data Bank. Am J Surg 2006, 192:710-714.

96. Krinsley JS, Grover A: Severe hypoglycemia in critically ill patients: risk factors and outcomes. Crit Care Med 2007, 35:2262-2267.

97. Lee JH, Ryu YJ, Chun EM, Chang JH: Outcomes and prognostic factors for severe community-acquired pneumonia that requires mechanical ventilation. Korean J Intern Med 2007, 22:157-163.

98. Liao KM, Chen CW, Hsiue TR, Lin WC: Timing of acute respiratory distress syndrome onset is related to patient outcome. J Formos Med Assoc 2009, 108:694-703.

99. Lin JL, Lin-Tan DT, Chu PH, Chen YC, Huang YL, Ho TC, Lin CY: Cadmium excretion predicting hospital mortality and illness severity of critically ill medical patients. Crit Care Med 2009, 37:957-962.

100. Lin SM, Wang TY, Liu WT, Chang CC, Lin HC, Liu CY, Wang CH, Huang CD, Lee KY, Kuo HP: Predictive factors for mortality among non-HIV-infected patients with pulmonary tuberculosis and respiratory failure. Int J Tuberc Lung Dis 2009, 13:335-340.

101. Martin GS, Mannino DM, Moss M: The effect of age on the development and outcome of adult sepsis. Crit Care Med 2006, 34:15-21

102. Mitchell I, Finfer S, Bellomo R, Higlett T: Management of blood glucose in the critically ill in Australia and New Zealand: a practice survey and inception cohort study. Intensive Care Med 2006, 32:867-874
103. Mowery NT, Dortch MJ, Dossett LA, Norris PR, Diaz JJ Jr, Morris JA Jr, May AK: Insulin resistance despite tight glucose control is associated with mortality in critically ill surgical patients. J Intensive Care Med 2009, 24:242-251.

104. Mowery NT, Gunter OL, Guillamondegui O, Dossett LA, Dortch MJ, Morris JA Jr, May AK: Stress insulin resistance is a marker for mortality in traumatic brain injury. J Trauma 2009, 66:145-151.

105. Murphy CV, Schramm GE, Doherty JA, Reichley RM, Gajic O, Afessa B, Micek ST, Kollef MH: The importance of fluid management in acute lung injury secondary to septic shock. Chest 2009, 136:102-109.

106. Nair S, Vanatta JM, Arteh J, Eason JD: Effects of obesity, diabetes, and prior abdominal surgery on resource utilization in liver transplantation: a single-center study. Liver Transp/ 2009, 15:1519-1524.

107. Pieracci FM, Hydo L, Pomp A, Eachempati SR, Shou J, Barie PS: The relationship between body mass index and postoperative mortality from critical illness. Obes Surg 2008, 18:501-507.

108. Quach S, Hennessy DA, Faris P, Fong A, Quan H, Doig C: A comparison between the APACHE II and Charlson Index Score for predicting hospital mortality in critically ill patients. BMC Health Serv Res 2009, 9:129.

109. Rady MY, Johnson DJ, Patel B, Larson J, Helmers R: Cortisol levels and corticosteroid administration fail to predict mortality in critical illness: the confounding effects of organ dysfunction and sex. Arch Surg 2005, 140:661-668.

110. Ranucci M, Pazzaglia A, Bianchini C, Bozzetti G, Isgro G: Body size, gender, and transfusions as determinants of outcome after coronary operations. Ann Thorac Surg 2008, 85:481-486.

111. Rellos K, Falagas ME, Vardakas KZ, Sermaides G, Michalopoulos A: Outcome of critically ill oldest-old patients (aged 90 and older) admitted to the intensive care unit. J Am Geriatr Soc 2006, 54:110-114.

112. Rivero-Ayerza M, Scholte op Reimer W, Lenzen M, Theuns DAMJ, Jordaens L, Komajda M, Follath F, Swedberg K, Cleland JGF: New-onset atrial fibrillation is an independent predictor of in-hospital mortality in hospitalized heart failure patients: results of the EuroHeart Failure Survey. Eur Heart J 2008, 29:1618-1624.

113. Rosamel P, Cervantes M, Tristan A, Thivolet-Béjui F, Bastien O, Obadia JF Lehot JJ: Active infectious endocarditis: postoperative outcome. $J$ Cardiothorac Vasc Anesth 2005, 19:435-439.

114. Rose AH, Kotzé A, Doolan D, Norfolk DR, Bellamy MC: Massive transfusion: evaluation of current clinical practice and outcome in two large teaching hospital trusts in Northern England. Vox Sang 2009, 97:247-253.

115. Sailhamer EA, Carson K, Chang Y, Zacharias N, Spaniolas K, Tabbara M, Alam HB, DeMoya MA, Velmahos GC: Fulminant Clostridium difficile colitis: patterns of care and predictors of mortality. Arch Surg 2009, 144:433-439.

116. Sakr $Y$, Vincent JL, Ruokonen E, Pizzamiglio M, Installe E, Reinhart K, Moreno R, Sepsis Occurrence in Acutely III Patients Investigators: Sepsis and organ system failure are major determinants of post-intensive care unit mortality. J Crit Care 2008, 23:475-483.

117. Sayed S, Fischer S, Karck M, Hassouna A, Haverich A: Effect of different preoperative patient characteristics on coronary surgery outcome: a comparative study between a developing and a developed country. J Card Surg 2009, 24:275-280.

118. Shah KB, Nolan MM, Rao K, Wang DJ, Christenson RH, Shanholtz CB, Mehra MR, Gottlieb SS: The characteristics and prognostic importance of NT-ProBNP concentrations in critically ill patients. Am J Med 2007, 120:1071-1077.

119. Bezerra da Silva G Jr, De Francesco Daher E, Salani Mota RM, Menezes FA: Risk factors for death among critically ill patients with acute renal failure. Sao Paulo Med J 2006, 124:257-263.

120. Sleiman I, Morandi A, Sabatini T, Ranhoff A, Ricci A, Rozzini R, Trabucchi M: Hyperglycemia as a predictor of in-hospital mortality in elderly patients without diabetes mellitus admitted to a sub-intensive care unit. J Am Geriatr Soc 2008, 56:1106-1110.

121. Smith RL, Chong TW, Hedrick TL, Hughes MG, Evans HL, McElearney ST, Pruett TL, Sawyer RG: Does body mass index affect infection-related outcomes in the intensive care unit? Surg Infect (Larchmt) 2007, 8:581-588.

122. Svircevic V, Nierich AP, Moons KG, Brandon Bravo Bruinsma GJ, Kalkman CJ, van Dijk D: Fast-track anesthesia and cardiac surgery: a retrospective cohort study of 7989 patients. Anesth Analg 2009, 108:727-733.

123. Thielmann M, Massoudy P, Neuhäuser M, Tsagakis K, Marggraf G, Kamler M, Mann K, Erbel R, Jakob H: Prognostic value of preoperative cardiac troponin I in patients undergoing emergency coronary artery bypass 
surgery with non-ST-elevation or ST-elevation acute coronary syndromes. Circulation 2006, 114(1 Suppl):1448-1453.

124. Tsai CW, Lin YF, Wu VC, Chu TS, Chen YM, Hu FC, Wu KD, Ko WJ, NSARF Study Group: SAPS 3 at dialysis commencement is predictive of hospital mortality in patients supported by extracorporeal membrane oxygenation and acute dialysis. Eur J Cardiothorac Surg 2008, 34:1158-1164.

125. Tseng CC, Fang WF, Huang KT, Chang PW, Tu ML, Shiang YP, Douglas IS, Lin MC: Risk factors for mortality in patients with nosocomial Stenotrophomonas maltophilia pneumonia. Infect Control Hosp Epidemiol 2009, 30:1193-1202.

126. Vandijck DM, Oeyen SG, Buyle EM, Claus BO, Blot SI, Decruyenaere JM: Hyperglycaemia upon onset of ICU-acquired bloodstream infection is associated with adverse outcome in a mixed ICU population. Anaesth Intensive Care 2008, 36:25-29.

127. Vardakas KZ, Michalopoulos A, Kiriakidou KG, Siampli EP, Samonis G, Falagas ME: Candidaemia: incidence, risk factors, characteristics and outcomes in immunocompetent critically ill patients. Clin Microbiol Infect 2009, 15:289-292.

128. Vasile VC, Babuin L, Rio Perez JA, Alegria JR, Song LM, Chai HS, Afessa B, Jaffe AS: Long-term prognostic significance of elevated cardiac troponin levels in critically ill patients with acute gastrointestinal bleeding. Crit Care Med 2009, 37:140-147.

129. Vincent JL, Rello J, Marshall J, Silva E, Anzueto A, Martin CD, Moreno R, Lipman J, Gomersall C, Sakr Y, Reinhart K, EPIC II Group of Investigators: International study of the prevalence and outcomes of infection in intensive care units. JAMA 2009, 302:2323-2329.

130. Wasir H, Mehta Y, Pawar M, Choudhary A, Kohli V, Meharwal ZS, Bapna RK, Malhotra R, Trehan N: Predictors of operative mortality following primary coronary artery bypass surgery. Indian Heart J 2006, 58:144-148.

131. Yavas S, Yagar S, Mavioglu L, Cetin E, Iscan HZ, Ulus AT, Birincioglu CL: Tracheostomy: how and when should it be done in cardiovascular surgery ICU? J Card Surg 2009, 24:11-18

132. Ylipalosaari P, Ala-Kokko TI, Laurila J, Ohtonen P, Syrjälä H: Intensive care acquired infection is an independent risk factor for hospital mortality: a prospective cohort study. Crit Care 2006, 10:R66.

133. Yoshimoto A, Nakamura H, Fujimura M, Nakao S: Severe communityacquired pneumonia in an intensive care unit: risk factors for mortality. Intern Med 2005, 44:710-716.

134. Zangrillo A, Landoni G, Fumagalli L, Bove T, Bellotti F, Sottocorna O, Roberti A, Marino G: Methicillin-resistant Staphylococcus species in a cardiac surgical intensive care unit: a 5-year experience. J Cardiothorac Vasc Anesth 2006, 20:31-37.

135. Zarrilli R, Casillo R, Di PA, Tripodi MF, Bagattini M, Cuccurullo S, Crivaro V, Ragone E, Mattei A, Galdieri N, Triassi M, Utili R: Molecular epidemiology of a clonal outbreak of multidrug-resistant Acinetobacter baumannii in a university hospital in Italy. Clin Microbiol Infect 2007, 13:481-489.

136. Ailawadi G, Swenson BR, Girotti ME, Gazoni LM, Peeler BB, Kern JA, Fedoruk LM, Kron IL: Is mitral valve repair superior to replacement in elderly patients? Ann Thorac Surg 2008, 86:77-85.

137. Almog Y, Novack V, Megralishvili R, Kobal S, Barski L, King D, Zahger D: Plasma level of $\mathrm{N}$ terminal pro-brain natriuretic peptide as a prognostic marker in critically ill patients. Anesth Analg 2006, 102:1809-1815.

138. Chien JY, Jerng JS, Yu CJ, Yang PC: Low serum level of high-density lipoprotein cholesterol is a poor prognostic factor for severe sepsis. Crit Care Med 2005, 33:1688-1693.

139. Connelly KA, Creati L, Lyon W, Yii M, Rosalion A, Wilson AC, Santamaria J, Jelinek VM: Early and late results of combined mitral-aortic valve surgery. Heart Lung Circ 2007, 16:410-415.

140. Cuthbertson BH, Croal BL, Rae D, Gibson PH, McNeilly JD, Jeffrey RR, Smith WC, Prescott GJ, Buchan KG, El-Shafei H, Gibson GA, Hillis GS: Nterminal pro-B-type natriuretic peptide levels and early outcome after cardiac surgery: a prospective cohort study. Br J Anaesth 2009, 103:647-653.

141. Djavani K, Wanhainen A, Valtysson J, Björck M: Colonic ischaemia and intra-abdominal hypertension following open repair of ruptured abdominal aortic aneurysm. Br J Surg 2009, 96:621-627.

142. Dünser MW, Ruokonen E, Pettilä V, Ulmer H, Torgersen C, Schmittinger CA Jakob S, Takala J: Association of arterial blood pressure and vasopressor load with septic shock mortality: a post hoc analysis of a multicenter trial. Crit Care 2009, 13:R181.
143. Ganesh JS, Rogers CA, Banner NR, Bonser RS, Steering Group of the UK Cardiothoracic Transplant Audit: Does the method of lung preservation influence outcome after transplantation? An analysis of 681 consecutive procedures. J Thorac Cardiovasc Surg 2007, 134:1313-1321.

144. Karimi A, Ahmadi H, Davoodi S, Movahedi N, Marzban M, Abbasi K, Omran AS, Sadeghian S, Yazdanifard P, Abbasi SH, Fallah N: Factors affecting postoperative morbidity and mortality in isolated coronary artery bypass graft surgery. Surg Today 2008, 38:890-898.

145. Kenneally C, Rosini JM, Skrupky LP, Doherty JA, Hollands JM, Martinez E, McKinzie WE, Murphy T, Smith JR, Micek ST, Kollef MH: Analysis of 30-day mortality for Clostridium difficile-associated disease in the ICU setting. Chest 2007, 132:418-424.

146. Kes VB, Solter W, Supanc V, Demarin V: Impact of hyperglycemia on ischemic stroke mortality in diabetic and non-diabetic patients. Ann Saudi Med 2007, 27:352-355.

147. Musci M, Weng Y, Hübler M, Chavez T, Qedra N, Kosky S, Stein J, Siniawski H, Hetzer R: Predictors of early mortality in patients with active infective native or prosthetic aortic root endocarditis undergoing homograft aortic root replacement. Clin Res Cardiol 2009, 98:443-450

148. Patel NV, Woznick AR, Welsh KS, Bendick PJ, Boura JA, Mucci SJ: Predictors of mortality after muscle flap advancement for deep sternal wound infections. Plast Reconstr Surg 2009, 123:132-138.

149. Paul M, Bishara J, Levcovich A, Chowers M, Goldberg E, Singer P, Lev S, Leon P, Raskin M, Yahav D, Leibovici L: Effectiveness and safety of colistin: prospective comparative cohort study. I Antimicrob Chemother 2010, 65:1019-1027.

150. Stegenga ME, Vincent JL, Vail GM, Xie J, Haney DJ, Williams MD, Bernard GR, van der Poll T: Diabetes does not alter mortality or hemostatic and inflammatory responses in patients with severe sepsis. Crit Care Med 2010, 38:539-545.

151. Vincent JL, Sakr Y, Sprung C, Harboe S, Damas P, Sepsis Occurrence in Acutely III Patients (SOAP) Investigators: Are blood transfusions associated with greater mortality rates? Results of the Sepsis Occurrence in Acutely III Patients study. Anesthesiology 2008, 108:31-39.

152. Zare MM, Itani KM, Schifftner TL, Henderson WG, Khuri SF: Mortality after nonemergent major surgery performed on Friday versus Monday through Wednesday. Ann Surg 2007, 246:866-874.

153. Zilberberg MD, Shorr AF, Micek ST, Doherty JA, Kollef MH: Clostridium difficile-associated disease and mortality among the elderly critically ill. Crit Care Med 2009, 37:2583-2589.

154. Waller BF, Palumbo PJ, Lie JT, Roberts WC: Status of the coronary arteries at necropsy in diabetes mellitus with onset after age 30 years: analysis of 229 diabetic patients with and without clinical evidence of coronary heart disease and comparison to 183 control subjects. Am J Med 1980, 69:498-506.

155. Woodfield SL, Lundergan CF, Reiner JS, Greenhouse SW, Thompson MA, Rohrbeck SC, Deychak Y, Simoons ML, Califf RM, Topol EJ, Ross AM: Angiographic findings and outcome in diabetic patients treated with thrombolytic therapy for acute myocardial infarction: the GUSTO-I experience. J Am Coll Cardiol 1996, 28:1661-1669.

156. Krinsley JS: Association between hyperglycemia and increased hospital mortality in a heterogeneous population of critically ill patients. Mayo Clin Proc 2003, 78:1471-1478.

157. Falciglia M, Freyberg RW, Almenoff PL, D'Alessio DA, Render ML: Hyperglycemia-related mortality in critically ill patients varies with admission diagnosis. Crit Care Med 2009, 37:3001-3009.

158. Rady MY, Johnson DJ, Patel BM, Larson JS, Helmers RA: Influence of individual characteristics on outcome of glycemic control in intensive care unit patients with or without diabetes mellitus. Mayo Clin Proc 2005, 80:1558-1567.

doi:10.1186/cc10440

Cite this article as: Siegelaar et al:: The effect of diabetes on mortality in critically ill patients: a systematic review and meta-analysis. Critical Care 2011 15:R205. 